\title{
Temporal Variation of Coefficient of Consolidation and its Effect on PVD Consolidation
}

\author{
Amitava Chakraborti ${ }^{1 *}$, Gupinath Bhandari ${ }^{1}$, Sibapriya Mukherjee ${ }^{1}$ \\ *_Corresponding Author \\ ${ }^{1}$ Department of Civil Engineering, \\ Jadavpur University, Kolkata 700032, India. \\ ${ }^{2}$ Dipanjan Basu \\ Department of Civil and Environmental Engineering, \\ University of Waterloo, Waterloo, \\ ON N2L 3G1, Canada.
}

\begin{abstract}
The installation of Prefabricated Vertical Drain (PVD) with preloading has become one of the most preferred and efficient technique for ground improvement of soft clay. A number of oil storage tanks of varied capacities were proposed on soft clayey subsoil at Budge Budge, $(20 \mathrm{Km}$ South of Kolkata) South 24 Parganas, located quite close to river Hooghly in West Bengal, India. Installation of PVD followed by preloading was adopted as a ground improvement technique, which was appropriate for the site to achieve, the required bearing capacity and settlement within a short time. Progress of the consolidation process was monitored periodically and at regular intervals. The settlement and pore pressure dissipation were measured with the help of settlement plates and pore pressure transducers. The observed time-settlement data have been analyzed to obtain the coefficient of consolidation in the horizontal direction. The variation of the Coefficient of Consolidation $\left(C_{h}\right)$ with respect to time has been plotted and a relationship has been established to study the variation of Coefficient of Consolidation with time.

It has been found that $C_{h}$ values vary with time as well as settlement. $C_{h}$ varied from $0.00442 \mathrm{~m}^{2} / \mathrm{day}$ to $0.191128 \mathrm{~m}^{2} / \mathrm{day}$, when applied surcharge load varies from $21.6 \mathrm{kN} / \mathrm{m}^{2}$ to $115.0 \mathrm{kN} / \mathrm{m}^{2}$, in stages, over a period of 30 days. This paper highlights the nature of variation of Coefficient of Consolidation $\left(C_{h}\right)$ under a given surcharge over time.
\end{abstract}

KeyWords: Vertical Drain; Preloading; Ground improvement; Coefficient of Consolidation.

\section{INTRODUCTION}

Prefabricated Vertical drains (PVD) along with surcharge loading are being extensively used for ground improvement in soft clay. The process is eco friendly, less expensive and easy to operate. A vertical drain consists of a slender, synthetic core with vertical grooves functioning as drain. Geotextile sleeves are provided around the core, which protects the grooves from clogging by acting as a filter. Installation of PVD is accomplished by pushing a steel mandrel into the ground up to the required depth. Excess pore water pressures caused by preloading finds an easy passage in the horizontal direction towards PVD and then along the vertical drain into the permeable drainage layers. Insertion of PVD shortens the drainage path, thereby accelerating the consolidation process. A desired degree of consolidation, which normally takes years, can be achieved within a few weeks.

Bharat Petroleum Corporation Limited (BPCL) in their effort to augment storage capacity at their Budge-Budge installation proposed to construct a number of oil storage tanks within their existing tank farm site, located quite close to river Hooghly. Jadavpur University was engaged by BPCL to provide solutions for ground improvement so as to complete the project within the available time. Eight Tanks were installed out of which one tank (T4) has been identified for detail monitoring.

It has been often reported (Chung, 1999; Bo et al.,2003; Arulrajah et al.2004) that the main difficulty faced for ground improvement using PVD is reliable prediction of settlement and time for consolidation. One of the possible reasons for inappropriate prediction of time and settlement can be attributed to the improper assessment of the horizontal coefficient of consolidation $\left(\mathrm{C}_{\mathrm{h}}\right)$, which is one of the most important factors for determination of rate of settlement. This hypothesis can be substantiated by the fact that variation of Coefficient of Consolidation $\left(\mathrm{C}_{\mathrm{h}}\right)$ with time and has not been considered for estimating the time and settlement. In construction loads are placed on the ground over a period of time and as a consequence of that consolidation of soil takes place. Permeability and compressibility of the soil are functions of void ratio therefore as the void ratio changes with time during the process of consolidation both the parameters are expected to change ( Rowe,1968; Indraratna et al.2005; Hsu and Liu 2013). Change in coefficient of consolidation with applied surcharge has been noted by Terzaghi et al.(1996); Seah and Juirnarongrit (2003).

Barron (1948) presented the basic comprehensive theoretical solution to the vertical drain assisted consolidation of soft soil, and since then many theoretical, empirical and approximate modifications (Hansbo 1979 ,1981 ,Holtz 1987,Bergado et al.1991,1993, Indraratna and Redana 1997,1998 Basu et al.2005) for predicting performance of PVD on soft soil have been developed. For estimation of coefficient of consolidation the graphical method proposed by Asaoka (1978) is extensively used, however the method is affected by individual skill set, and it underestimates the ultimate settlement depending on chosen time 
interval(Arulrajah et al.,2004,Edil et al.,1991). In this paper an attempt has been made to study the variation of coefficient of consolidation $\left(\mathrm{C}_{\mathrm{h}}\right)$ with time from observed field settlement data.

\section{FIELD SUB SOIL PROFILE}

The subsoil of BudgeBudge, which is a part of Indo-Gangetic plains of West Bengal and similar to Normal Kolkata soil, consists of layers of normally consolidated, soft alluvial clay deposit of low shear strength.

A detailed subsoil investigation was made at the site. 14 boreholes up to a depth of 20 meters were made at different locations. Disturbed and undisturbed soil samples were collected and tested at Jadavpur University soil mechanics laboratory. Details of average subsoil profile are shown in Table 1.

\subsection{Estimation of Ground settlement with and without PVD}

Additional Pressure on the ground:

Height of the tank- $13.50 \mathrm{~m}$

Diameter of the Tank $-29.00 \mathrm{~m}$

Load from Hydro test (tanks will be filled with water for testing) $\quad=135.00 \mathrm{kN} / \mathrm{m}^{2}$

Load, from $0.76 \mathrm{~m}$ sand pad $0.76 \mathrm{~m} \mathrm{x} 18.00 \mathrm{kN} / \mathrm{m}^{3}$ (unit wt of sand) $=13.70 \mathrm{kN} / \mathrm{m}^{2}$.

Load intensity from self weight of Tank $=260 \mathrm{kN} / \pi \mathrm{x}(29 \mathrm{~m})^{2} \quad=3.90 \mathrm{kN} / \mathrm{m}^{2}$.

Load for raising of ground by $1.00 \mathrm{~m} \quad=1 \times 18.00 \mathrm{kN} / \mathrm{m}^{2}=18.00 \mathrm{kN} / \mathrm{m}^{2}$.

Total Pressure at Ground: $135.00+13.7+3.9+18.00=170.6 \mathrm{kN} / \mathrm{m}^{2}$. Say, $\quad 170.00 \mathrm{kN} / \mathrm{m}^{2}$.

Net foundation pressure $=\mathrm{Q}_{\mathrm{net}}=170.00 \mathrm{kN} / \mathrm{m}^{2}$.

\subsection{Bearing Capacity check}

Most of the loads will be carried by strata I and II

Average $C_{u}=(26.0 \times 2.5+22.0 \times 8.5+49.03 \times 3.0) / 14=28.50 \mathrm{kN} / \mathrm{m}^{2}$.

Ultimate Bearing capacity

$\mathrm{Qult}_{\mathrm{ult}}=\mathrm{C} \mathrm{N}_{\mathrm{c}}=28.50 * 5.7 \quad=162.50 \mathrm{kN} / \mathrm{m}^{2}$

$\left(\mathrm{N}_{\mathrm{c}}=\right.$ Terzaghi's Bearing capacity factor $)$

Applying a factor of safety of 2.0

Qallow $=81.00 \mathrm{kN} / \mathrm{m}^{2}$.

Hence, Ground Improvement was considered necessary.

\subsection{Estimation of Settlement of untreated soil.}

Settlement $\mathrm{S}=m_{v} \cdot \Delta \mathrm{p} . \mathrm{H}$

(where, $\Delta \mathrm{p}=$ change in vertical stress $m_{v}$. = Coefficient of volume compressibility

and $\mathrm{H}=$ height $/$ depth of soil layer)

Time required for settlement $(\mathrm{t}) \mathrm{t}=\frac{T_{v} \cdot H^{2}}{C_{v}}$

(where, $T_{v}=$ Time Factor and $C_{v}=$ Coefficient of vertical consolidation) 
Estimation of settlement of untreated soil (Based on 1 and 2) has been presented in Table 2.

Estimated total settlement $978 \mathrm{~mm}$ and time required for settlement $=31.88$ years.

The preloading was applied in two stages. Loose sand and sand bags, were used for preloading. Coarse sand (unit weight 18.00 $\mathrm{kN} / \mathrm{m}^{2}$ ) was used up to a height of $2.3 \mathrm{~m}$, beyond that, due to non-availability of coarse sand, fine sand (unit weight 15.60 $\mathrm{kN} / \mathrm{m}^{2}$ ) was used for the rest of the $4.7 \mathrm{~m}$. total Height of preload being $7 \mathrm{~m}$, Total load of $115.00 \mathrm{kN} / \mathrm{m}^{2}(2.3 \times 18.00+4.7 \times 15.6)$, was envisaged to be applied in two stages. In the first stage pre load of $57.00 \mathrm{kN} / \mathrm{m}^{2}$ and in the second stage pre load of 58.00 $\mathrm{kN} / \mathrm{m}^{2}$ was applied.

\subsection{Change in shear strength after consolidation by preloading:}

The soil is normally Consolidated $(N C)$. First two layers will undergo maximum changes.

It is known that, $\Delta C_{u} / \Delta p_{1}=0.25$

( Som,N.N. and Das,S.C. 2003)

Where, $\Delta C_{u}=$ Change in shear strength. $\quad \Delta p_{1}=$ Change in vertical stress.

Stratum I.

$\Delta \mathrm{p}_{1}=115.00 \mathrm{kN} / \mathrm{m}^{2}$

therefore, $\Delta \mathrm{C}_{\mathrm{u}}=0.25 \times 115.00=28.75 \mathrm{kN} / \mathrm{m}^{2}$.

Stratum II

$\Delta \mathrm{p}_{1}=0.96 \times 115.00 \mathrm{kN} / \mathrm{m}^{2}=110.4 \mathrm{kN} / \mathrm{m}^{2}$ ( Considering 2:1 dispersion of load )

therefore $\Delta \mathrm{C}_{\mathrm{u}}=0.25 \mathrm{x} 110.4=27.5 \mathrm{kN} / \mathrm{m}^{2}$.

Additional load from hydro test $=\left(170.00 \mathrm{kN} / \mathrm{m}^{2}-115.00 \mathrm{kN} / \mathrm{m}^{2}\right)=65.00 \mathrm{kN} / \mathrm{m}^{2}$.

(Oil storage tanks are tested for settlement etc, by filling the tanks up to the full capacity with water before Commissioning, this is known as Hydro test, )

Change in shear Strength after consolidation by load from Hydro test:

(PVD were designed, considering 90\% consolidation)

Stratum I

$\Delta \mathrm{p}_{1}=\left(65.0 \times 29^{2}\right) \times .9 /(29+1.25)^{2}=53.70 \mathrm{kN} / \mathrm{m}^{2}$. Therefore, $\Delta \mathrm{C}_{\mathrm{u}}=0.25 \times 53.7=13.42 \mathrm{kN} / \mathrm{m}^{2}$.

Stratum II

$\left.\Delta \mathrm{p}_{1}=65.0 \times 29^{2}\right) \times .9 /(29+2.5+4.25)^{2}=38.40 \mathrm{kN} / \mathrm{m}^{2}$. Therefore, $\Delta \mathrm{C}_{\mathrm{u}}=0.25 \times 38.4=9.60 \mathrm{kN} / \mathrm{m}^{2}$.

Shear Strength of Soil after hydro test :

For Stratum $\mathrm{I}=26.0+28.75+13.42=68.17 \mathrm{kN} / \mathrm{m}^{2}$

For Stratum II $=22.0+27.50+9.6=59.10 \mathrm{kN} / \mathrm{m}^{2}$.

Average $C_{u}=(2.5 \times 68.17+8.5 \times 59.10) / 11=61.16 \mathrm{kN} / \mathrm{m}^{2}$.

So, $\left(Q_{\text {ult }}\right)_{\text {net }}=6 \times 61.16=366.96 \mathrm{kN} / \mathrm{m}^{2}$.

Factor of safety $($ F.S $)=366.6 / 170.00=2.15$.

Settlements in stage I and stage II were $333 \mathrm{~mm}$ and $347 \mathrm{~mm}$ respectively

Settlement during Stage I of the preload $\left(\mathrm{P}_{\mathrm{c}}=57.00 \mathrm{kN} / \mathrm{m}^{2}\right)$ has been presented in Table 3 .

Settlement during Stage II of the preload $\left(\mathrm{P}_{\mathrm{c}}=58.00 \mathrm{kN} / \mathrm{m}^{2}\right)$ has been presented in Table 4 . 
Total settlement considering both the stages of consolidation $=680.00 \mathrm{~mm}$.

Settlement considering both stages and $90 \%$ consolidation $=612.00 \mathrm{~mm}$.

\subsection{The design of PVD}

From the calculations it is evident that the first two layers will undergo maximum settlement, hence band drain will be required in these layers. Both the layers can be considered as an equivalent single layer of thickness $11.0 \mathrm{~m}$ and average $\mathrm{Cu}$ of $23.00 \mathrm{kN} / \mathrm{m}^{2}$.

Time required for $90 \%$ consolidation using Band drain is given by Barron (1948):

$$
\mathrm{t}=\frac{D^{2}}{8 C_{h}} \times\left[\ln \left(\frac{D}{d}\right)-\frac{3}{4}\right] \times \ln \left(\frac{1}{1-U}\right)
$$

$\mathrm{t}=$ time required for consolidation, (in years).

$\mathrm{D}=$ Influence diameter of drain, (in meters) $=1.05 \times$ spacing of $\mathrm{PVD}=1.05 \times 0.75=0.787 \mathrm{~m}$

(Installation of band drains in triangular pattern).

Equivalent diameter of drain-

$\mathrm{d}=2(\mathrm{w}+\mathrm{t}) / \pi=2(100+4) / 3.14=66.20 \mathrm{~mm}$ or $0.066 \mathrm{~m}$

$C_{h}=$ Coefficient of radial Consolidation $=2 \times C_{v}=3 \times 1.52=3.04 \mathrm{~m}^{2} /$ year.

(Assuming $\mathrm{C}_{\mathrm{h}} / \mathrm{C}_{\mathrm{v}}=2$ for soft clayey soil ( as per practice)

$\mathrm{U}=$ Degree of consolidation settlement $=90 \%$.

Therefore, $\mathrm{t}=0.1717$ years $=62.68$ days $=$ say 63 days.

PVD of size $100 \mathrm{mmx} 4 \mathrm{~mm}$ and length 15 mters at the rate of 0.75 meters in Triangular pattern has been installed. A layer of geotextile, of tensile strength of $100 \mathrm{kN}$ in both directions, has been provided below sand pad to reduce differential settlement.

\subsection{INSTALLATION OF PVD AND PRELOADING}

The installations of PVD and arrangement of surcharge load are shown in Fig 1 .

Installation was started by laying a $400 \mathrm{~mm}$ thick sand layer, to make the ground suitable for movement of crawler crane. Locations of each of the PVD were carefully marked on the ground.A 40 ton capacity crawler mounted crane operated band drain installer was used to push a rectangular mandrel (Size 100x35 mm) on the ground. PVDs were installed to a depth of $15 \mathrm{~m}$ from the ground. PVDs were cut off leaving $600 \mathrm{~mm}$ above the ground. A drainage layer of $300 \mathrm{~mm}$ thick coarse sand, with a gentle slope towards the outer periphery, was placed. Arrangements were made to drain the discharged water into the nearby brick lined surface drain. On top of the drainage blanket a woven geotextile was spread over the entire treated area. Preloading had started after installation of band drains, placement of drainage blanket and laying of geotextile. Sand and sand bags were placed in a systematic and staged manner up to the designed height of $7 \mathrm{~m}$.

\subsection{Field Instrumentation:}

After installation of PVDs,(and before preloading,) four Settlement gauges (one in the middle and 3 in the outer periphery at a distance of $10 \mathrm{~m}$ from centre and two Piezometers, at depths, approx $2.5 \mathrm{~m}$ and $9.1 \mathrm{~m}$ were carefully placed. Settlements were measured with respect to a fixed bench marks, located outside the tank firm area. 


\subsection{RESULTS AND DISCUSSIONS}

An attempt has been made in this study, to determine coefficient of consolidation from the analysis of temporal variation of $\mathrm{C}_{\mathrm{h}}$.

\subsection{Settlement Vs Time curve}

On completion of installation of PVDs, placement of drainage layer and installation of necessary instruments, preloading with sand bags and sand were accomplished in staged manners. Settlements were recorded twice and pore pressures were recorded four times daily.

It can be seen from the time-settlement curve (Fig 3.) that settlement started almost immediately and continued at a slow rate .Whenever additional surcharge loads were applied the rate of settlement increased to some extent, This slow rate of settlement continued till $32^{\text {nd }}$ day. The rate of settlement increased when the surcharge load was increased to $115.00 \mathrm{kN} / \mathrm{m}^{2}$ from 68.00 $\mathrm{kN} / \mathrm{m}^{2}$ (approximately). Preloading was paused for approx 11days and settlements observed during this period were $54 \mathrm{~mm}$ and $48 \mathrm{~mm}$. From the time vs settlement curve (Fig 3) it can also be seen that the rate of settlement was slow till $59 \%$ of the surcharge load was applied. After placement of final load on the $55^{\text {th }}$ day, settlement at much faster rates were observed, this was further substantiated by the observation that when preloading started after the pause, rate of settlement increased again. Final settlements of $607 \mathrm{~mm}$ and $503 \mathrm{~mm}$ in centre and peripheral gauges were observed. Settlement nearly stopped after 88 days, that was, after 33 days from the final loading .

It may be mentioned here, that river Hooghly is at a distance of about $500 \mathrm{~m}$ from the site. On close monitoring it has been observed that, tidal variation did not show any effect on in the pore pressure.

\subsection{Estimation of Time of consolidation with temporal variation of $C_{h}$}

Time Settlement data from the site has been analyzed for determination of coefficient of Consolidation.

Degree of Consolidation (U) for equal strain condition is given by

$$
U=1-e^{\frac{-8 T}{\mu}} \quad \text { (Barron 1948) }
$$

When, $\mathrm{T}=$ Time factor,

$$
\mu=\frac{n^{2}}{(1-n)} \log _{e}(n)-\frac{3 n^{2}-1}{4 n^{2}}
$$

And $n=\frac{d_{e}}{d_{w}}$

where, $d_{e}$ and $d_{w}=$ equivalent diameter of soil cylinder and drain.

Eq. 2 can be modified as,

$T=\frac{-\mu \ln (1-U)}{8}$

$U=\frac{S_{1,2,3 \ldots}}{S_{\text {Total }}}$

Degree of Consolidation (U) at different time has been computed by dividing measured settlement $\left(\mathrm{S}_{1,2,3 \ldots}\right)$ at a particular time by total settlement $\left(S_{\text {total }}\right)$

Bromwell and Lambe,(1968) showed that - Coefficient consolidation :

$C_{h}=\frac{T_{h 2}-T_{h 1}}{t_{2}-t_{1}} \times d_{e}^{2}$ 
Where, $T_{h 1}$ and $T_{h 2}$ are time factors for Time $t_{1}$ and $t_{2}$ respectively.

Variation of Coefficient of Consolidation with time, has been plotted in Fig 4.

It has been found that $\mathrm{C}_{\mathrm{h}}$ values vary with the time $(\mathrm{t})$ as settlement progresses. $\mathrm{C}_{\mathrm{h}}$ varied from $0.00424 \mathrm{~m}^{2} / \mathrm{day}\left(1.551 \mathrm{~m}^{2} / \mathrm{yr}\right)$ to $0.07468 \mathrm{~m}^{2} /$ day $\left(27.259 \mathrm{~m}^{2} / \mathrm{yr}\right)$ on $80^{\text {th }}$ day.

From Fig 4. It can be seen that up to $50^{\text {th }}$ day the $C_{h}$ varies between $0.00424 \mathrm{~m}^{2} /$ day and $0.01409 \mathrm{~m}^{2} /$ day (when, approximately $60 \%$ of the surcharge load has been applied) , after this, Coefficient of consolidation $\left(\mathrm{C}_{\mathrm{h}}\right)$ changed at faster rates, from 0.01409 $\mathrm{m}^{2} /$ day to $0.07468 \mathrm{~m}^{2} /$ day till $80^{\text {th }}$ day, and then drops to $0.04443 \mathrm{~m}^{2} /$ day on the $85^{\text {th }}$ day. It can be observed from Fig 4 that $C_{h}$ does not remain constant during the entire period of settlement; it varies with time as well as with surcharge.

That $C_{h}$ increases with time from the beginning of the application of surcharge till the completion of primary consolidation and start to decrease thereafter can be attributed to the variation of Time factor ( $\mathrm{T}$ ) and Degree of Consolidation (U) with time. Fundamentally $\mathrm{T}$ and $\mathrm{U}$ increases with time during consolidation and it may be considered to have reached a constant value after completion of consolidation. Hence the product of ' $\mathrm{C}_{h}$ ' and ' $\mathrm{t}$ ' increase during consolidation. Thus it may be found that $\mathrm{C}_{h}$ increases with the increase in time ( $t$ ) to fulfill this phenomenon. On the other hand at the end of the primary consolidation the product is considered to have reached a constant value. Hence $C_{h}$ is found to decrease with time after the primary consolidation has been completed.

Variation of Coefficient of consolidation $\left(\mathrm{C}_{\mathrm{h}}\right)$ with time and Degree of Consolidation (U\%)

has been presented in Fig 5. It can be seen that the $C_{h}$ varies with time and degree of

Consolidation.

From the Fig 4 it is observed that consolidation calculations can be divided in parts i) when surcharge load is gradually applied ,and ii) when consolidation under a constant surcharge takes place. Variation of $\mathrm{C}_{\mathrm{h}}$ during the latter part of the present study can be approximated by a, best fit, equation

$$
C_{h}\left(\times 10^{-3}\right)=t^{2}-55.5 t+653 \text { (where ' } \mathrm{t} \text { ' is Time in days ). }
$$

This equation can be used to find out the coefficient of consolidation for a particular time and subsequent Degree of consolidation for that period .

The variation in Degree of Consolidation (U\%) considering $C_{h}$ as constant and $C_{h}$ as variable can be seen in Fig 6. The rapid change of $\mathrm{C}_{\mathrm{h}}$, if considered,will result in more realistic prediction of both degree and time of Consolidation.

\section{CONCLUSIONS:}

Main findings from the Study may be concluded as follows:

1) $C_{h}$ does not remain constant over the period of consolidation .Variation of $C_{h}$ depends on the extent of surcharge load and time.

2) Change in the increasing trend in the value of $C_{h}$ indicates end of primary consolidation. Variation of Coefficient of consolidation after application of full surcharge, can be approximated by a, best fit, quadratic equation:

$C_{h}\left(10^{-3}\right)=t^{2}-55.5 t+653 \quad$ (' $\mathrm{t}$ ' is Time in days).

\section{REFERENCES:}

[1] Asaoka, A (1978). "Observational procedure of settlement prediction” Soils and Foundation Journal. Japan Geotech Soc., 18(4), 87-101.

[2] Barron, R. A. (1948) "Consolidation of fine grained soils by drain wells.” Transaction of the American Society of Civil Engineers 113, paper 2346, 718-54

[3] Basu. D., Basu, P., and Prezzi, M. (2006). "Analytical solutions for consolidation aided by the vertical drains." Geomech Geoeng Int J 1(1), 63-71.

[4] Bergado, D. T., Alfaro, M. C., and Balasubramaniam, A. S. (1993). "Improvement of soft Bangkok clay using vertical drains." Geotext Geomembr $12,567-586$.

[5] Bromwell,L.G., and Lamb,W.T. (1968) "Comparison of Laboratory and Field Values of C for Boston Blue Clay". Soils Publication 205 Massachusetts Institute of Technology, Cambridge, Massachusetts 
[6] Hansbo,S.(1981).“Consolidation of fine grained soil by prefabricated drains.”In Proc.10 ${ }^{\text {th }}$ International Conference on Soil Mechanics and Foundation Engineering, 3 Stolkholm, 677-82.

[7] Hansbo, S. (1987). "Design aspects of vertical drains and lime column installations." In Proc. $9^{\text {th }}$ Southeast Asian geotechnical conference, Bangkok, $1-12$.

[8] Holtz, R. D. and Christopher, B. R. (1988). “Characteristics of prefabricated drain for accelerating consolidation." In Proc. $9^{\text {th }}$ European Conference on Soil Mechanics and Foundation Engineering, Dublin, 2, 903-06.

[9] Hsu,T.-W.,and Liu,H.-J.(2013) "Consolidation of radial drainage under time dependent loading” Journal of the Geotechnical and Geoenvironmental Engineering Vol.139, No 12.

[10] Seah,T.H.,and Juirnarongrit,T (2003) "Constant rate of strin consolidation with radial drainage” Geotech.Test.J.,26(4),432 -443.

[11] Som,N.N., and Das,S.C.(2003) “Theory and Practice of Foundation Design” Prentice Hall

[12] of India Private Limited.New Delhi. pp 335-340.

\section{LIST OF TABLES}

Table 1: Average Sub Soil profile.

Table 2: Estimation of Settlement of untreated soil.

Table 3: Estimation of Settlement during Stage I of preload $\left(P_{c}=57.00 \mathrm{kN} / \mathrm{m}^{2}\right)$

Table 4: Estimation of Settlement during Stage II of preload $\left(P_{c}=58.00 \mathrm{kN} / \mathrm{m}^{2}\right)$

Table 1: Average Sub Soil profile

\begin{tabular}{|c|c|c|c|c|c|c|c|c|}
\hline $\begin{array}{l}\text { Depth } \\
(\mathrm{m})\end{array}$ & $\begin{array}{l}\text { Description } \\
\text { Of the Soil }\end{array}$ & $\begin{array}{l}\text { Bulk } \\
\text { Density } \\
\mathrm{kN} / \mathrm{m}^{3}\end{array}$ & $\begin{array}{r}\text { Cohesion } \\
\left(\mathrm{kN} / \mathrm{m}^{2}\right)\end{array}$ & $\begin{array}{l}\mathrm{LL} \\
(\%)\end{array}$ & $\begin{array}{l}\mathrm{PL} \\
(\%)\end{array}$ & $\begin{array}{l}\text { Moisture } \\
\text { Content } \\
(\%)\end{array}$ & $\begin{array}{l}\text { N-Value } \\
\text { (no) }\end{array}$ & $\begin{array}{l}* * \mathrm{C}_{\mathrm{v}} \\
\left(\mathrm{m}^{2} / \mathrm{yr}\right)\end{array}$ \\
\hline $\begin{array}{c}1 \\
\text { To } \\
3.5 \\
\end{array}$ & $\begin{array}{l}\text { Soft } \\
\text { Brownish } \\
\text { Silty- Clay } \\
\end{array}$ & 18.10 & 26.0 & 52 & 20 & 32 & 3 to 4 & 1.52 \\
\hline $\begin{array}{c}3.5 \\
\text { To } \\
12.0\end{array}$ & $\begin{array}{l}\text { Soft dark- grey Silty-Clay } \\
\text { with } \\
\text { Decomposed wood }\end{array}$ & 17.20 & 22.00 & 62 & 27 & 38 & 2 to 6 & 1.52 \\
\hline $\begin{array}{c}12.0 \\
\text { to } \\
15.0 \\
\end{array}$ & $\begin{array}{l}\text { Medium Bluish-Grey } \\
\text {,silty clay }\end{array}$ & 18.60 & 50.0 & 58 & 23 & 29 & 7 to 15 & -- \\
\hline
\end{tabular}

***eefficient of vertical consolidation $\left(\mathrm{C}_{\mathrm{v}}\right)$.

*Ground water level was at ground level.

Table 2: Estimation of Settlement of untreated soil.

\begin{tabular}{|l|l|l|l|l|l|}
\hline layer & $\begin{array}{l}\text { Height }(\mathrm{H}) \\
(\mathrm{m})\end{array}$ & $\begin{array}{c}\Delta p \\
\left(\mathrm{kN} / \mathrm{m}^{2}\right.\end{array}$ & $\begin{array}{l}\mathrm{m}_{\mathrm{v}} \\
\left(\mathrm{m}^{2} / \mathrm{kN}\right)\end{array}$ & Settlement (mm) & time (year) \\
\hline I & 2.5 & 157.00 & 0.06 & 235 & 19.23 \\
\hline II & 8.5 & 116.00 & 0.07 & 693 & 10.95 \\
\hline III & 3.0 & 83.30 & 0.02 & 050 & 1.67 \\
\hline & & & Total & 978 & 31.88 \\
\hline
\end{tabular}

$* *$ Coefficient of vertical consolidation $\left(\mathrm{C}_{\mathrm{v}}\right)=1.52 \mathrm{~m}^{2} /$ year.

Table 3 . Estimation of Settlement during Stage I of preload $\left(\mathrm{P}_{\mathrm{c}}=57.00 \mathrm{kN} / \mathrm{m}^{2}\right)$

\begin{tabular}{|c|c|c|c|c|}
\hline Layer & $\begin{array}{c}\text { Height } \\
(\mathrm{m})\end{array}$ & $\begin{array}{c}\Delta \mathrm{P} \\
\left(\mathrm{kN} / \mathrm{m}^{2}\right)\end{array}$ & $\begin{array}{c}\mathrm{m}_{\mathrm{v}} \\
\left(\mathrm{m}^{2} / \mathrm{kN}\right)\end{array}$ & Settlement $(\mathrm{m})$ \\
\hline I & 2.5 & 52.40 & 0.06 & 0.076 \\
\hline II & 8.5 & 40.50 & 0.07 & 0.241 \\
\hline III & 3.0 & 28.60 & 0.02 & 0.016 \\
\hline & \multicolumn{2}{|c|}{ Total Settlement (m) } \\
\hline
\end{tabular}


Table 4. Settlement during Stage II of preload $\left(\mathrm{P}_{\mathrm{c}}=58.00 \mathrm{kN} / \mathrm{m}^{2}\right)$

\begin{tabular}{|c|c|c|c|c|}
\hline layer & $\begin{array}{c}\text { Height } \\
\text { (in m) }\end{array}$ & $\begin{array}{c}\Delta \mathrm{P} \\
\left(\mathrm{N} / \mathrm{m}^{2}\right)\end{array}$ & $\begin{array}{c}\mathrm{m}_{\mathrm{v}} \\
\left(\mathrm{m}^{2} / \mathrm{kN}\right)\end{array}$ & Settlement $(\mathrm{m})$ \\
\hline I & 2.5 & 53.30 & 0.06 & 0.080 \\
\hline II & 8.5 & 41.90 & 0.07 & 0.249 \\
\hline III & 3.0 & 30.60 & 0.02 & 0.018 \\
\hline & \multicolumn{3}{|c|}{ Total Settlement $(\mathrm{m})$} & 0.347 \\
\hline
\end{tabular}

\section{LIST OF FIGURES}

Fig:1. Schematic Diagram showing Sub-Soil Profile and Surcharge load

Fig.2. PVD installation is in progress at site.

Fig 3. Time vs. Settlements Curves .

Fig 4. Time vs Coefficient of Consolidation

Fig 5. Variation of Coefficient of consolidation with time and Degree of Consolidation

Fig 6. Comparison of Degree of Consolidation considering $C_{h}$ as constant $V s C_{h}$ as variable.

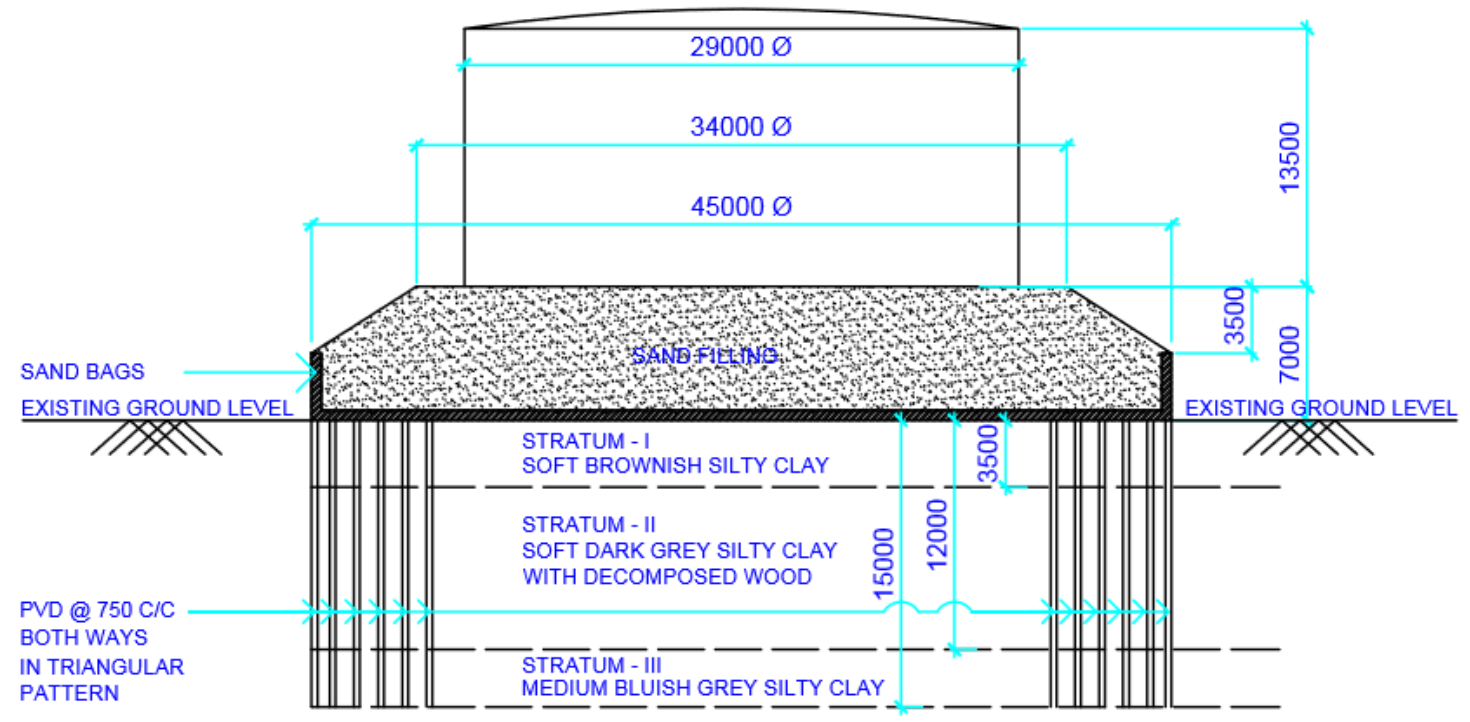

ALL DIMENSIONS ARE IN MM.

UNLESS OTHER WISE STATED

(NOT TO SCALE)

Fig:1. Schematic Diagram showing Sub-Soil Profile and Surcharge load 


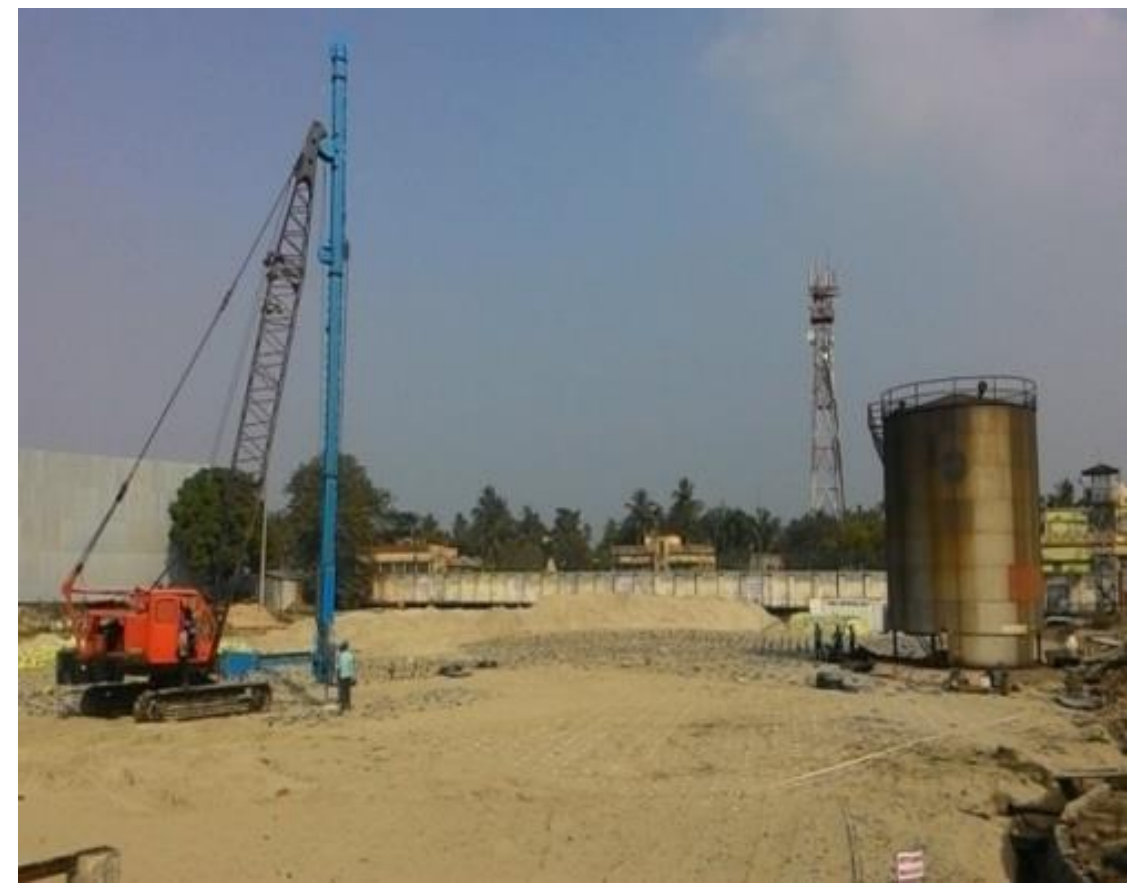

Fig.2. PVD installation is in progress at site.

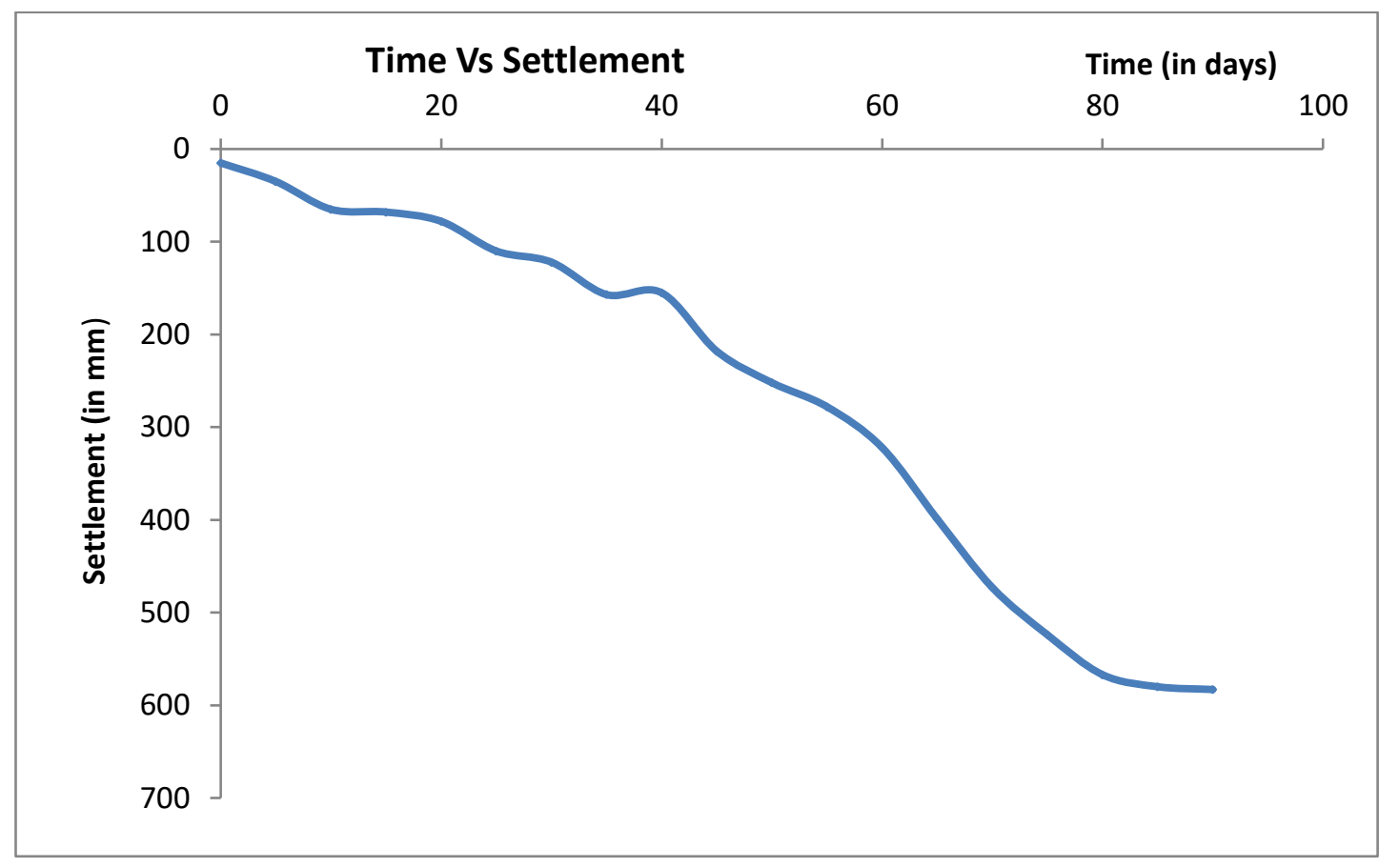

Fig 3. Time vs. Settlement Curve. 


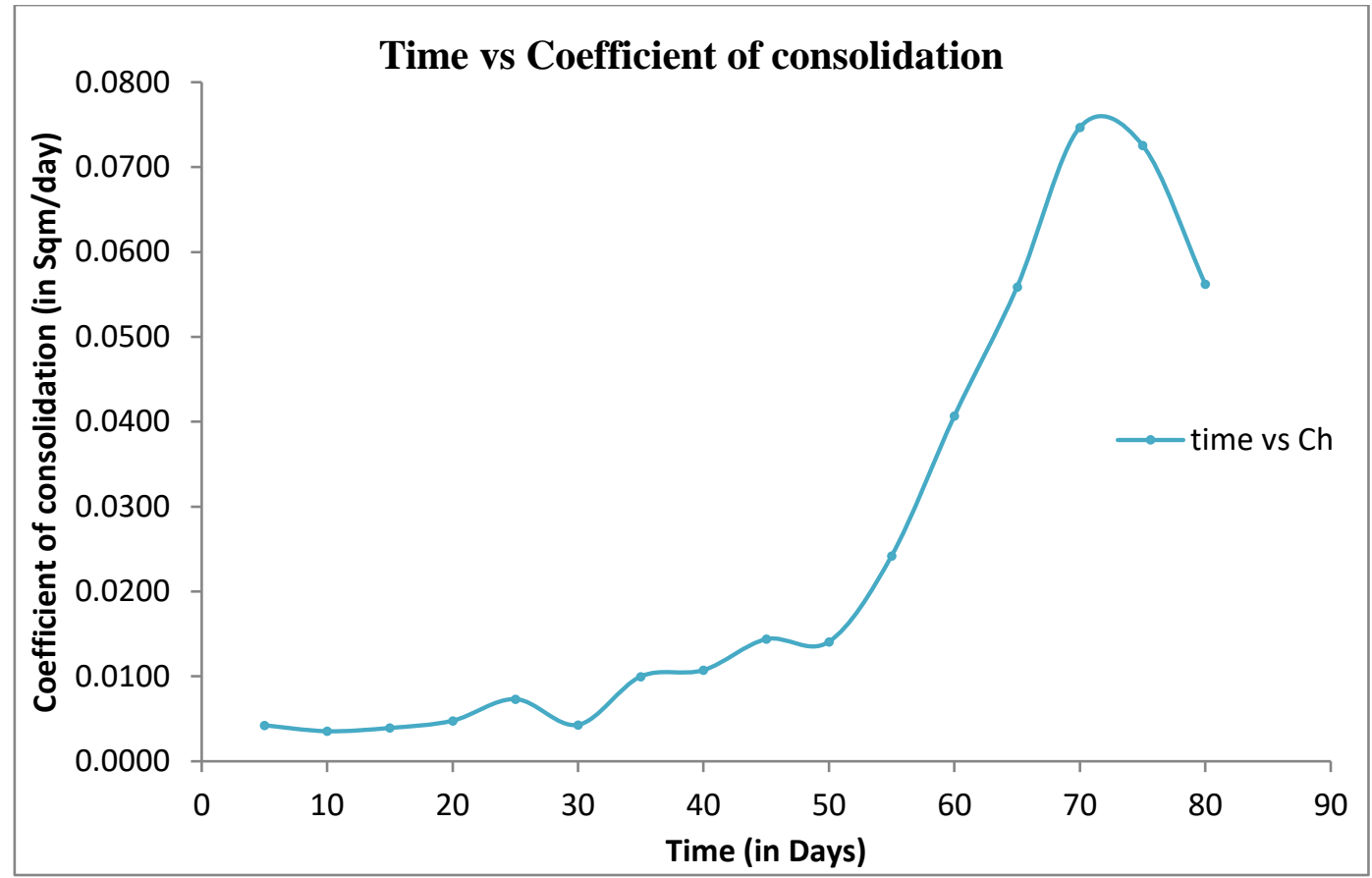

Fig 4. Time vs Coefficient of Consolidation

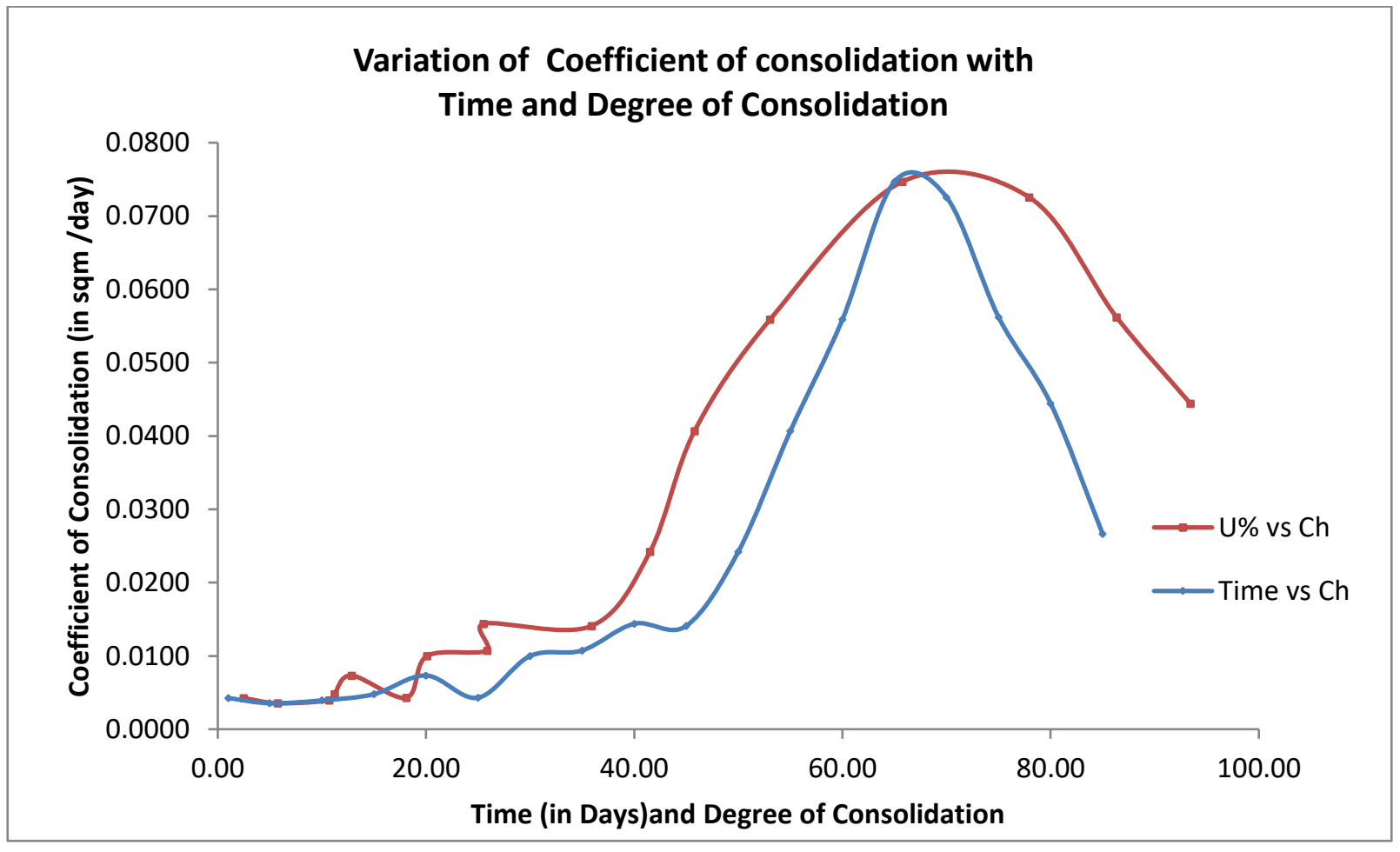

Fig 5. Variation of Coefficient of consolidation with time and Degree of Consolidation 


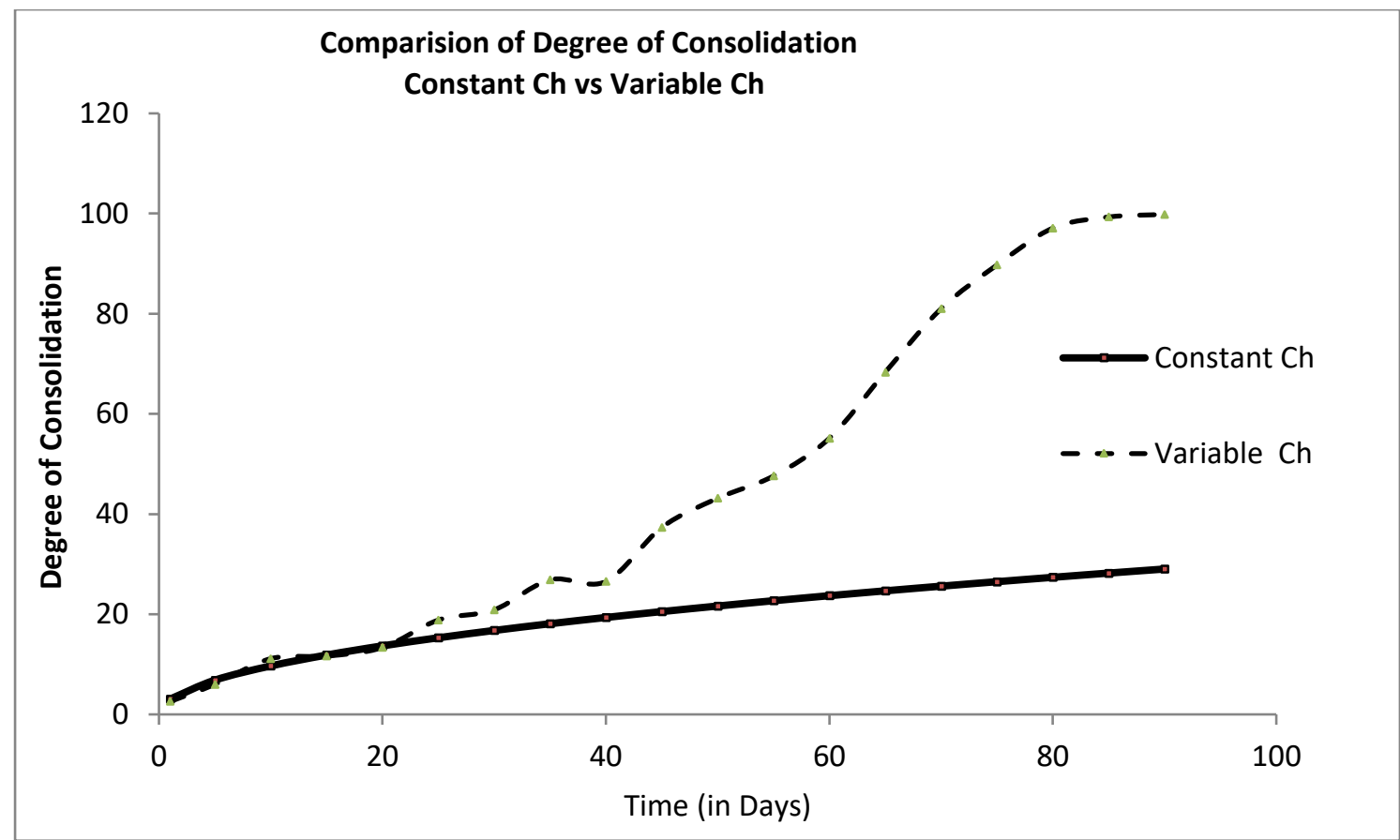

Fig 6. Degree of Consolidation considering $C_{h}$ as constant $V s C_{h}$ as variable. 